\title{
Corporate greening: is it significant for biodiversity conservation?
}

\author{
JOHN G. ROBINSON
}

The TEEB (The Economics of Ecosystems and Biodiversity) Report for Business (2010) recognized a new positive presence in biodiversity conservation-the private corporation. This recognition was the culmination of the transformation of the corporation, in the eyes of some, from rapacious exploiter of nature to conservation saviour. The transformation was aided by the development of policies and practices of Corporate Social Responsibility, which began to be adopted by firms in the mid 1980s. Corporate Social Responsibility initiatives are voluntary efforts by companies to address social, environmental and human rights concerns arising from business activities. It was helped along by the recognition by the Convention of Biological Diversity in their 2002 strategic plan that private firms were full partners in the Convention's efforts. It was endorsed by the plethora of partnerships and collaborations that have been established between private corporations and conservation organizations.

Many conservationists dismiss this corporate greening as marketing green-wash. The private sector is after all directly implicated, by the very nature of business, in the harvest of wild species, the exploitation of natural resources, the conversion of natural areas and the generation of waste material. But if private corporations are able and willing to mitigate the negative environmental impacts of their business activities there could be significant conservation consequences. The land under private management, or influenced through smallholders, suppliers and contractors, is vast. Multinational corporations in particular have extensive supply chains reaching into all regions of the world. If companies would incorporate the ideas of longterm sustainability into their use of natural resources, and lighten their global footprint, then biodiversity losses could be reduced.

Private companies could even act more positively, and by their investments, activities and actions actively promote conservation. A joint IUCN-Shell study (Bishop et al., 2008) promoted the potential of corporations to transform the conservation endeavour, and the TEEB Report strongly endorsed the idea of making 'biodiversity conservation a viable business proposition'.

Turning the power of the private sector so that it results in better biodiversity outcomes is a seductive proposition. Over the last 20 years conservation organizations have taken on that challenge. Some of the earliest collaborations

John G. Robinson Wildlife Conservation Society, 2300 Southern Boulevard, Bronx, New York 10460, USA. E-mail jrobinson@wcs.org between firms and conservation organizations, such as that between the Environmental Defense Fund and McDonald's Hamburgers in 1990, focused on environmental impact. Fauna \& Flora International took an early lead in extending efforts to mitigate environmental impacts, especially with extractive industries. More recently the emphasis has been on promoting conservation as a business opportunity. In 1998 the Business Environmental Leadership Council, for instance, was established by the Pew Center to promote private involvement in efficient, effective solutions to the problem of climate change. In 2001 Conservation International and the Ford Motor Company created the Center for Environmental Leadership in Business to encourage companies to develop innovative solutions to critical environmental problems. One of the Center's actions was to create the Energy and Biodiversity Initiative, which brought together a group of civil society organizations with oil companies, with the aim, in addition to minimizing negative impacts of exploration and extraction, of enhancing biodiversity conservation in and around industrial operations.

Realistically however, what can corporations do to mitigate the impact of their business operations? How much can they positively contribute to the conservation of biodiversity and the maintenance of ecosystem services? If corporations ultimately have to be responsive to their shareholders' requirements for profitability can they also respond to conservation needs? Yes answer enthusiasts from both the corporate and conservation sectors to this last question. Profitability need not be incompatible with contributing to social and environmental good. They advocate a triple bottom line of financial, social and environmental objectives, and enthusiastically believe in win-win-win situations.

How realistic is all of this? To reduce the losses to the biodiversity ledger there is a broad consensus that many companies can lessen their environmental impact and, through the process of reducing waste and inefficiencies, also improve the financial bottom line. The ability of companies to do so will probably vary with the business sector. Those that depend on renewable natural resources (e.g. hunting, wildlife trade, fishing and forestry) have greater opportunities to make their operations more sustainable than those that rely on conversion of natural habitat (e.g. soya or palm oil production), or extractive industries (e.g. hydrocarbons or mining). Some supply chains of global commodities are more amenable to environmental mitigation than others: different commodities have different harvest/extractive costs, transportation and storage costs, and production costs. Businesses can also reduce overall impacts by investing in activities that 
preclude even greater biodiversity losses. For instance, ecotourism or harvesting and retailing natural products could provide financial incentives that discourage the conversion of natural areas into other land uses. However, the available reporting suggests that, for most companies, although the social and environmental costs of operations may be improved, achieving a true triple bottom line remains more of an aspiration than a reality.

The exceptions to this conclusion are businesses that directly enhance the gains to the biodiversity ledger, such as those that directly help protect natural systems. Private firms could become more active in carbon trading, which could reduce deforestation and mitigate climate change. Mining companies could adopt net positive impact standards (as suggested by the Rio Tinto mining company) that would offset biodiversity impacts and actually enhance biodiversity outcomes. Companies could invest more in wildlife-friendly markets, harnessing the purchasing power of the consumer towards green products. Retailing to green consumers at a premium price could allow investments in conservation. To date, however, corporate involvement in these kinds of markets has been limited, and companies ascribe their reluctance to the absence of an appropriate policy and financial enabling environment.

Another question is to what extent the corporate sector as a whole is actively responding to the environmental challenge. The largest corporate forum is the $\mathrm{UN}$-sponsored Global Compact, which has c. 3,60o companies as members, including about one-fifth of the Global Fortune 500 companies. These numbers are encouraging until one considers that there are some 78,000 multinational corporations in the world, and some 780,000 additional companies affiliated with these multinationals. Nevertheless, the conservation strategy has been for NGOs to engage with the largest and leading companies in a sector with the hope to 'identify the best, and move the rest'. The efficacy of this strategy remains unclear. We do know that the longer-standing parallel effort to get the corporate world to adopt better labour practices and occupational safety standards has not been generally successful. With increasing globalization of the market, the pattern has been for companies to relocate to countries with weaker labour standards and governmental regulation, and to squeeze subcontractors and suppliers to reduce costs. It is not clear that the response to the environmental challenge will be very different, although a number of large companies (Walmart, Coca-Cola, Cargill, Rio Tinto, Shell Oil, J.P.
Morgan Chase, the PPR Group, to name a few in different sectors) have been pushing to mitigate the impact of their operations and to make active contributions to conservation within their business model. As many of these have extensive supply chains, or control significant proportions of the global trade in certain commodities, they could pull along others in the sector-but the jury is still out on whether this will happen.

Corporations are new actors on the conservation stage. To date, the reviews are mixed on whether they can be strong contributors to conservation. Most companies still follow the admonition of The Economist (2005): 'The proper business of business is business. No apology required'. Even those companies that have positioned themselves as responsive to concerns have not been able to demonstrate improved conservation outcomes. Early indications are that the corporations will not have a starring role but could play a supporting role if an enabling environment of policies, government regulations and societal expectations can align business interests with conservation outcomes. Ensuring that appropriate enabling environment, and in general delivering conservation outcomes, will probably remain inevitably in the traditional domain of government and civil society.

\section{Acknowledgements}

The opportunity to think about these issues came through a sabbatical, hosted by Nigel Leader-Williams through Churchill College, and the Department of Geography, at the University of Cambridge, UK. I thank many for comments on related manuscripts and Elizabeth Bennett for comments on this editorial.

\section{References}

Bishop, J., Kapila, S., Hicks, F., Mitchell, P. \& Vorhies, F. (2008) Building Biodiversity Business. Shell International Ltd and IUCN, London, UK, and Gland, Switzerland.

The ECONomist (2005) The Good Company: A Survey of Corporate Social Responsibility. 20 January.

TEEB (The EConomics of Ecosystems and Biodiversity) (2010) The Economics of Ecosystems and Biodiversity: Report for Business Http://www.teebweb.org/Portals/25/Documents/TEEB\%2ofor\%20 Business/TEEB\%2ofor\%2oBus\%2oExec\%2oEnglish.pdf [accessed 1 September 2010]. 